\title{
On family meetings
}

\section{Section Editor}

Anne W. McCammon, MD, FAAN

David Y. Chung, MD, $\mathrm{PhD}$

Correspondence to

Dr. Chung:

dychung@mgh.harvard.edu
This is how you center clay.

Thump it on the wheel and get it whirring fast. Lay your wet hands onto it.

The clay will tell you what to do. Now, tell it back,

but do not startle it. Do not

bully the clay, because it will win.

You have to guide it to the center

as if the clay is making some terrible mistake

by being how it is. As if it is about

to expel Cordelia from the kingdom

for speaking the truth and you've got to stop it without being expelled yourself. Poor Kent!

You will try and try, but how can you save the king without losing a part of yourself, and how can you give yourself over like that? 


\section{Neurology}

\section{On family meetings}

David Y. Chung

Neurology 2016;87;1183

DOI 10.1212/WNL.0000000000003086

This information is current as of September 12, 2016

\section{Updated Information \& Services}

\section{Subspecialty Collections}

Permissions \& Licensing

\section{Reprints}

including high resolution figures, can be found at: http://n.neurology.org/content/87/11/1183.full

This article, along with others on similar topics, appears in the following collection(s):

All Clinical Neurology

http://n.neurology.org/cgi/collection/all_clinical_neurology

All Ethics in Neurology/Legal issues

http://n.neurology.org/cgi/collection/all_ethics_in_neurology_legal_iss ues

\section{Critical care}

http://n.neurology.org/cgi/collection/critical_care

Prognosis

http://n.neurology.org/cgi/collection/prognosis

Information about reproducing this article in parts (figures,tables) or in its entirety can be found online at:

http://www.neurology.org/about/about_the_journal\#permissions

Information about ordering reprints can be found online:

http://n.neurology.org/subscribers/advertise

Neurology ${ }^{\circledR}$ is the official journal of the American Academy of Neurology. Published continuously since 1951, it is now a weekly with 48 issues per year. Copyright @ 2016 American Academy of Neurology. All rights reserved. Print ISSN: 0028-3878. Online ISSN: 1526-632X.

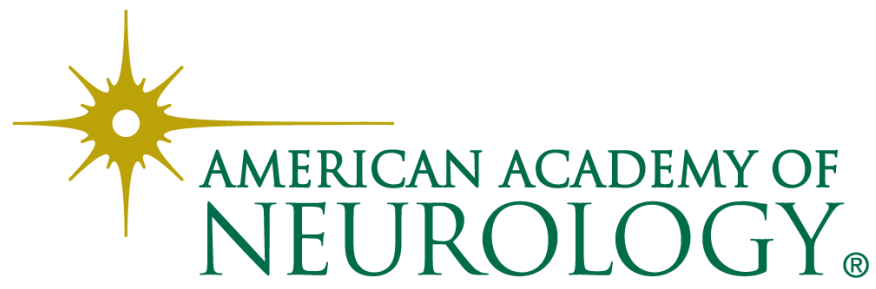

